\title{
MENGUNGKAP LANDASAN FILOSOFIS KEILMUAN BIMBINGAN KONSELING ISLAM
}

\author{
Komarudin \\ Universitas Islam Negeri (UIN) Walisongo Semarang Jawa Tengah \\ E-mail:komarudin@walisongo.ac.id
}

\begin{abstract}
This article examines the philosophical foundations of Islamic counseling guidance. Any scientific discipline produced by ijtihadi process must be historical. Therefore, the scientific status of a science is no longer placed parallel to the sacred doctrine, so it is taken for granted. Similarly, the existence of Islamic counseling guidance should not be placed higher above other counseling theories, or other scientific disciplines of counseling. Counseling process that is part of humanitarian activities, if used as one of the objects of scientific studies, should give birth to a scientific discipline that is historical. The right approach, therefore, appropriate for the study of it, would be more humanistic-transcendental rather than transcendental-theological. Based on the ontological studies, there is no significant ontological difference between Islamic counseling and other counseling disciplines. Both are only distinguished from the aspect of counselor status and spirit of morality that is used as paying counseling activities.
\end{abstract}

Keywords: Da'wah Science; Counseling; Philosophy

\begin{abstract}
ABSTRAK
Artikel ini mengkaji tentang landasan filosofis keilmuan bimbingan konseling Islam. Setiap disiplin keilmuan dihasilkan berdasarkan proses ijtihadi pasti bersifat histories. Oleh karena itu, status keilmuan suatu ilmu tidak lagi harus ditempatkan sejajar dengan doktrin suci, sehingga bersifat taken for granted. Begitu pula dengan keberadaan bimbingan konseling Islam, sudah sepantasnya tidak ditempatkan lebih tinggi di atas teori-teori konseling yang lain, atau disiplin-disiplin keilmuan konseling lainnya. Proses konseling yang merupakan bagian dari aktifitas
\end{abstract}


kemanusiaan, bila dijadikan sebagai salah satu obyek kajian keilmuan, seharusnya melahirkan suatu disiplin keilmuan yang bersifat histories. Oleh karena itu, pendekatan yang semestinya tepat untuk kajian mengenai hal itu lebih cocok bersifat humanistic-transendental, ketimbang teologistransendental. Berdasarkan kajian ontologisnya, antara konseling Islam dengan disiplin konseling lainnya, tidak memiliki perbedaan landasan ontologis yang signifikan. Di antara keduanya hanya dibedakan dari aspek status konselornya dan spirit moralitas yang dijadikan sebagai paying aktifitas konseling.

Kata Kunci: Filsafat; Keilmuan Dakwah; Konseling

\section{A. Pendahuluan}

Perkembangan model-model relasi yang terjadi dalam interaksi manusia tidak lagi hanya dirumuskan dalam bentuk struktural-institusional, yang terimplementasikan dalam wadah institusi-institusi sosial yang ada, tetapi sudah berkembang ke arah bentuk hubungan timbal-balik yang saling menguntungkan dan membutuhkan. Hubungan timbal balik seperti hal tersebut dalam disiplin konseling sering diistilahkan dengan istilah the helping relationship (Shertzer/Stone, 1980: 5). Eksistensi hubungan yang bersifat timbal-alik tersebut tak mungkin bisa dinegasikan, mengingat keberadaan manusia sendiri yang secara kodrati sebagai makhluk sosial. Artinya, dalam fakta-realitasnya, tidak ada satu orang pun yang mampu hidup di jagad raya ini secara mandiri tanpa memerlukan uluran tangan dan bantuan dari sesama. Fakta lain juga menunjukkan bahwa setiap manusia yang hidup di dunia, hampir pasti memiliki masalah (problems), meskipun dalam kadar dan tingkatan yang berbeda-beda. Sehingga dengan demikian, dapat ditegaskan bahwa kehidupan itu sendiri adalah masalah, tanpa masalah berarti tanpa kehidupan. Life is problems, no life without problems. Ini berarti bahwa sepanjang manusia diberi kehidupan, maka sepanjang itu pula berbagai masalah akan bermunculan, yang harus dihadapi dan dipecahkan. Tindakan untuk memecahkan masalah demi masalah yang dihadapi tersebut, telah melahirkan sebuah peradaban yang sangat spektakuler dalam rentang panggung sejarah kehidupan umat manusia.

Akan tetapi, fakta lain juga menunjukkan bahwa tidak setiap manusia memiliki cukup kemampuan dan keahlian dalam mencari solusi yang tepat dan terbaik, untuk mengatasi setiap permasalahan yang dihadapi. Ketidakmampuannya dalam mencari solusi terbaik tersebut, seringkali 
mengakibatkan bertumpuknya permasalahan demi permasalahan yang terkadang melahirkan depresi atau stres, gelisah, putus asa, dan berbagai penyakit kejiwaan lainnya. Ketidakmampuan manusia tersebut merupakan suatu hal yang bersifat kodrati, meski ketidakmampuan yang dimilikinya tersebut sangat bersifat relatif dan dinamis. Artinya, setiap manusia masih diberi kesempatan untuk mengembangkan diri hingga ia semakin memiliki pertambahan kemampuan dalam mengatasi setiap permasalahan yang dihadapi. Meskipun demikian, ia tetap memiliki keterbatasan kemampuan, yang memaksanya tidak mungkin mampu mengatasi setiap permasalahan yang menimpanya, dengan mengandalkan kekuatan dirinya sendiri. Dari sinilah, maka menjadi jelas bahwa kehadiran orang lain yang memiliki kapabilitas dalam bidang-bidang tertentu, yang merupakan sisi dari kekurangannya, sangat diperlukan.

Salah satu permasalahan yang sering dihadapi manusia adalah masalah gangguan kesehatan mental (mental disorder). Tidak setiap manusia memiliki kemampuan untuk mendeteksi berbagai jenis gangguan yang menyerang aspek kejiwaannya. Meski terkadang ada orang yang mengetahui bahwa jiwanya sakit, namun tidak setiap dari mereka terkadang memiliki kemampuan untuk menemukan solusinya. Ia terkadang sangat membutuhkan pertolongan orang lain yang mampu memberikan bantuan agar permasalahan yang sedang dialami mampu terpecahkan.

Terkait dengan aktifitas pemberian bantuan terhadap masalah gangguan kejiwaan yang dialami oleh seseorang atau problem ketidakmampuan seseorang untuk mencari pemecahan terhadap setiap persoalan yang dihadapi, hal ini telah memunculkan paling tidak dua disiplin baru yang antara lain Bimbingan/Konseling dan Psikoterapi. Masing-masing istilah tersebut seringkali dibedakan satu sama lain. Istilah Konseling sering digunakan untuk menunjuk proses bantuan dimana klein yang dibantu diberi kesempatan untuk mengeksplorasi diri yang bisa mengarah pada terjadinya peningkatan kesadaran dan kemungkinan memilih. Selain itu, proses konseling seringkali berjangka pendek, difokuskan pada masalah-masalah tertentu, dan membantu individu (klein) dalam menyingkirkan hal-hal yang menghambat pertumbuhannya (Corey, 1988: 11). Melalui proses konseling, seorang individu juga dibantu untuk menemukan sumber-sumber pribadi agar dirinya bisa hidup lebih efektif. 
Sedangkan istilah Psikoterapi seringkali difokuskan pada proses-proses tak sadar serta labih banyak berurusan dengan pengubahan struktur kepribadian. Proses psikoterapi dilaksanakan lebih kearah pemahaman diri secara intensif, membutuhkan waktu yang relatif lama, tentang dinamikadinamika yang bertanggung jawab atas terjadinya krisis-krisis kehidupan, ketimbang hanya berurusan dengan usaha mengatasi krisis kehidupan tertentu, sebagaimana yang terjadi dalam proses konseling (Ibid:11-12).

Dalam kesempatan ini, penulis tertarik untuk mencermati lebih lanjut eksistensi disiplin Bimbingan dan konseling, yang keberadaannya merupakan salah satu bentuk implementasi dari the helping relationship. Hal yang menarik untuk dikaji lebih lanjut adalah masalah landasan filosofis dari the body of knowledge-nya. Secara filosofis, menurut Jujun S. Suriasumantri, ada tiga hal yang patut dipertanyakan terkait dengan keberadaan sebuah disiplin keilmuan. Ketiga hal tersebut meliputi aspek landasan ontologis, landasan epistemologis, dan landasan aksiologis suatu diisiplin ilmu (Suriasumantri, 1999: 35). Landasan ontologis menelaah masalah hakekat "apa” yang dikaji oleh suatu ilmu, landasan epistemologis hendak mengkaji cara mendapatkan pengetahuan yang benar, dan landasan aksiologis ilmu hendak mengkaji nilai kegunaan suatu ilmu.

Selanjutnya, disiplin Bimbingan dan Konseling sendiri dalam perkembangannya mulai menunjukkan varian-varian baru yang dilatarbelakangi "motif" agama. Sehingga di samping mulai munculnya istilah "konseling Pastoral" yang dikembangkan dalam tradisi Kristen, kini juga mulai muncul istilah "Bimbingan dan Konseling Islam" yang menjadi salah satu prodi dalam fakultas dakwah di lingkungan perguruan tinggi Islam. Meski belum begitu jelas eksistensi landasan filosofisnya serta kontekstualisasinya dengan disiplin ilmu dakwah, namun usaha-usaha untuk menggambarkan landasan filosofis the body of knowledge dari prodi Bimbingan dan Konseling Islam tersebut mulai dilakukan. Hal itu ditandai dengan berbagai penyelenggaraan seminar, workshop, dan diskusi rutin yang dilakukan oleh para ahli yang berkompentensi di bidangnya. Apalagi dengan bergulirnya "semangat" Islamisasi Ilmu, usaha ke arah penemuan jati diri prodi dan juga disiplin tersebut semakin digalakkan. Sesuatu yang pasti adalah bahwa eksistensi "Bimbingan dan Konseling Islam" tersebut masih dalam taraf on going process dan on going formation. Salah satu ide 
yang muncul dari diskusi tersebut adalah bahwa Bimbingan dan Konseling Islam yang dimaksud lebih cenderung dimaknai sebagai Konseling Islam, mengingat antara kedua istilah tersebut hanya memiliki perbedaan yang sangat tipis.

Meskipun, seandainya terjadi kesepakatan untuk mengubah istilah BKI ke KI, hal itu tetap menyisakan satu persoalan dasar yang belum tuntas, yaitu status landasan filosofis dari the body of knowledge-nya. Untuk kali ini, penulis hendak "meraba-raba" seperti apakah landasan ontologis dari Konseling Islam tersebut.

\section{B. Pembahasan}

\section{Pengertian Bimbingan dan Konseling Islam}

Istilah "Bimbingan" dan "konseling", secara bahasa memiliki akar kata yang berbeda. Istilah "bimbingan" berasal dari kata guidence yang berasal dari kata kerja to guide, yang berarti membimbing atau menunjukkan. Sementara istilah "Konseling" menurut asal kata dari bahasa latinnya, berasal dari kata consilium yang berarti "dengan" atau "bersama" yang dirangkai dengan "menerima” atau "memahami”. Sedangkan menurut asal kata dari bahasa Anglo-Saxon, istilah tersebut berasal dari kata sellen yang berarti "menyerahkan" atau "menyampaikan" (Prayitno dan Erman Amti, 1999: 100). Namun, dari segi pengertiannya, kedua istilah tersebut memiliki berbagai ragam pengertian, yang terkadang saling tumpang tindih, bahkan disamakan.

Pengertian "Bimbingan" sendiri menurut Bruce Shretzer dan Shelly C. Stone, diartikan sebagai the process of helping individuals to understand themselves and their world (Bruce Shrezer and Shelly C. Stone, 1966: 40). Menurut Prayitno dan Erman Amti pun, istilah tersebut di artikan sebagai "proses pemberian bantuan yang dilakukan oleh orang yang ahli kepada seseorang atau beberapa orang individu, baik anak-anak, remaja, maupun dewasa, agar orang yang dibimbing tersebut dapat mengembangkan kemampuan dirinya sendiri secara mandiri; dengan memanfaatkan kekuatan individu dan sarana yang ada serta dapat mengembangkan, berdasarkan norma-norma yang berlaku (Prayitno dan Erman Amti: 99).” Begitu pula menurut Bimo Walgito, bahwa secara umum istilah "Bimbingan" tersebut diartikan sebagai "suatu bantuan atau pertolongan 
yang diberikan kepada seorang individu atau sekelompok individu dalam menghindari atau mengatasi kesulitan-kesulitan di dalam kehidupannya, agar mereka dapat mencapai kesejahteraan hidupnya (Walgito, 1995: 4)."

Adapun pengertian "konseling” pun menurut Bruce Shretzer dan Shelly C. Stone diartikan sebagai an interaction process which facilitate meaningful understanding of self and environment and result in the establishment, and or clarification of goals and values for future behavior (Bruce Shrezer and Shelly C. Stone, 1968: 26). Menurut Prayitno dan Erman Amti pun, istilah "Konseling" tersebut diartikan sebagai "Proses pemberian bantuan yang dilakukan melalui wawancara konseling oleh seorang ahli (konselor) kepada individu yang sedang mengalami masalah (klien), yang bermuara pada teratasinya masalah yang dihadapi oleh klien tersebut (Prayitno dan Erman Amti: 99)." Sedangkan menurut Dewa Ketut Sukardi, istilah "Konseling" tersebut diartikan sebagai "Suatu upaya bantuan yang dilakukan dengan empat mata atau tatap muka antara konselor dan konseli, yang berisikan usaha yang laras, unik, human (manusiawi), yang dilakukan dalam suasana keahlian, dan yang didasarkan pada norma-norma yang berlaku, agar konseli memperoleh konsep diri dan kepercayaan diri sendiri dalam usahanya memperbaiki tingkah lakunya pada saat ini dan mungkin juga pada masa yang akan dating (Sukardi, 1989: 22).” Menurut Edwin C. Lewis, bahwa istilah "Konseling" tersebut diartikan sebagai, "Proses dimana orang yang bermasalah (klien) dibantu secara pribadi untuk berprilaku yang lebih memuaskan, melalui interaksi dengan seseorang yang tidak terlibat (konselor) yang menyediakan informasi dan reaksireaksi yang merangsang klien untuk mengembangkan prilaku-prilaku yang memungkinkan dirinya melakukan hubungan yang lebih efektif dengan lingkungannya (Efendi, 2005: 43).

Dari beberapa pengertian tersebut, tampak jelas bahwa di antara kedua istilah tersebut beberapa kesamaan, yaitu pertama, keduanya samasama diartikan sebagai suatu proses interaksi yang sama-sama bertujuan memberikan bantuan kepada fihak lain. Kedua, proses bantuan tersebut sama-sama dilakukan oleh seseorang yang ahli. Ketiga, proses pemberian bantuan tersebut dimaksudkan agar orang yang mendapatkan bantuan tersebut memiliki kemampuan untuk mengembangkan kemampuan dirinya secara mandiri, hingga permasalahan yang dihadapi bisa terselesaikan. 
Keempat, proses pemberian bantuan yang diberikan oleh seorang ahli tersebut memiliki fungsi yang sama, yaitu fungsi preventif, kuratif (korektif), preservatif, dan fungsi developmental (Faqih, 2001: 37). Kelima, subyek yang diberi bimbingan atau bantuan pun sama-sama terkadang terdiri dari satu orang atau beberapa orang (kelompok). Hanya saja, dalam proses "Konseling" terdapat beberapa kharakteristik yang tidak terdapat pada proses "Bimbingan" secara umum. Kharakteristik-kharakteristik yang dimaksud adalah, bahwa dalam proses "konseling” tersebut sangat ditentukan oleh setting tempat seseorang menjalankan praktek bimbingan, tipe dan metode pelayanan yang diberikan, serta taraf latihan yang diterima oleh seorang ahli.

Meskipun demikian, tidaklah tepat jika berdasarkan kharakteristik seperti itu, lantas proses konseling dibedakan secara mutlak (antagonisdiametral) dengan proses bimbingan. Barangkali yang paling tepat adalah melakukan komparasi antara "proses konseling" dengan berbagai bentuk the helping relationship lainnya, seperti dengan terapi psikologis. Oleh karena itu, hubungan antara "bimbingan" dan "konseling" lebih tepatnya digambarkan sebagai hubungan antara "pokok" dan "cabang". Atau, dengan kata lain, bahwa "konseling” merupakan salah satu bentuk layanan bimbingan atau bantuan, yang keberadaannya dibedakan dari berbagai jenis layanan atau bantuan lainnya. Atas dasar pemikiran seperti ini, maka istilah "Bimbingan dan Konseling" seharusnya boleh juga disebut dengan "Bimbingan Konseling".

\section{Formulasi Identitas Ontologi Keilmuan}

Sebagaimana telah disinggung di atas, bahwa semangat uforia Islamisasi ilmu telah menciptakan berbagai label "Islam" terhadap berbagai disiplin keilmuan, yang secara de facto ia telah tumbuh dan berkembang di sebuah "wilayah" yang secara kebetulan bukan dari daerah-daerah orang Islam. Dan, secara de facto pun para pelaku atau pengembang disiplindisiplin tersebut, bukanlah orang-orang (ilmuwan) yang tersinari oleh nilai-nilai keislaman. Atas dasar hal ini, sebagian intelektual Muslim kontemporer merasa perlu untuk melakukan islamisasi ilmu-ilmu pengetahuan, yang salah satunya adalah disiplin Bimbingan dan Konseling. 
Karena itu, kemudian muncul istilah "Bimbingan dan Konseling Islam" atau "Bimbingan Konseling Islam".

Istilah "Bimbingan Islam dan Konseling Islam" pun menurut beberapa Ahli cenderung dipisahkan, meskipun perbedaan tegas di antara keduanya juga sulit dijelaskan. Hal ini, sama dengan kasus pembedaan antara istilah "Bimbingan" dan "Konseling" itu sendiri. Alih-alih untuk mencari identitas, beberapa ahli memberikan definisi "Bimbingan Islami” sebagai berikut: pertama, Thohari Musnamar mengartikan istilah "Bimbingan Islami" sebagai, "Proses pemberian bantuan terhadap individu agar mampu hidup selaras dengan ketentuan Allah, sehingga dapat mencapai kebahagiaan di dunia dan akherat (Musnamar, 1992: 5)." Kedua, menurut Hallen A., bahwa istilah "bimbingan Islami” tersebut diartikan sebagai, "Proses pemberian bantuan yang terarah dan kontinyu serta sistematis kepada setiap individu, agar dia dapat mengembangkan potensi fitrah agama yang dimilikinya secara optimal, dengan cara menginternalisasikan nilai-nilai yang terkandung di dalam al-Qur'an dan Sunnah Rasulullah (Fadholiyono, 2005: 38).” Ketiga, menurut Aunur Rahim Faqih, bahwa istilah "Bimbingan Islami" tersebut juga diartikan sebagai, "Proses pemberian bantuan terhadap individu agar mampu hidup selaras dengan ketentuan dan petunjuk Allah, sehingga dapat mencapai kebahagiaan hidup di dunia dan akherat (Faqih, 2001: 4).”

Begitu pula istilah "Konseling Islami” pun juga diartikan dengan berbagai ragam arti. Menurut Thohari Musnamar sendiri, istilah tersebut diartikan sebagai, "Proses pemberian bantuan terhadap individu agar (dirinya) menyadari kembali kepada eksistensinya sebagai makhluk Allah yang seharusnya hidup selaras dengan ketentuan dan petunjuk Allah, sehingga (ia) dapat mencapai kebahagiaan hidup di dunia dan akherat (Musnamar: 5).” Menurut Hamdani Bakran adz-Dzaky, istilah tersebut diartikan sebagai, "Suatu aktifitas memberikan bimbingan, pelajaran, dan pedoman kepada individu yang meminta bimbingan (klien) dalam hal bagaimana seharusnya dirinya dapat mengembangkan potensi akal pikirannya, jiwanya, keimanannya, dan keyakinannya, serta dapat menanggulangi problematika hidup dengan lebih baik dan benar secara mandiri, yang berparadigma kepada al-Qur'an dan as-Sunnah Rasulullah saw (adz-Dzaky, 2001: 180).” Begitu juga menurut Imam Majid, bahwa 
istilah tersebut diartikan sebagai, "Proses pemberian bantuan kepada individu agar (dirinya) mampu mengembangkan kesadaran dan komitmen keragamannya sebagai hamba Allah dan khalifat Allah yang bertanggung jawab untuk mewujudkan kesejahteraan hidup bersama, baik secara fisik maupun psikis, atau, baik kebahagiaan hidup di dunia maupun di akherat (Rosjidan, 2004). Sedangkan menurut HM. Arifin, bahwa istilah tersebut diartikan sebagai, "Usaha pemberian bantuan kepada seseorang yang mengalami kesulitan, baik lahiriah maupun batiniah, yang menyangkut kehidupannya di masa kini dan di masa mendatang. Bantuan tersebut berupa pertolongan di bidang mental dan spiritual, agar orang yang bersangkutan mampu mengatasinya dengan kemampuan yang ada pada dirinya maupun dorongan dari kekuatan iman dan takwa kepada Allah (Arifin, 1994: 6).

Dari beberapa pengertian di atas, terlihat jelas bahwa perbedaan antara istilah "Bimbingan Islami" dengan "Konseling Islami” tidak memiliki perbedaan yang berarti. Hal ini sama dengan kasus perbedaan antara istilah "Bimbingan" dan "Konseling" itu sendiri. Kedua istilah tersebut samasama terkait dengan aktifitas the helping relationship, yang arah kegiatannya dimaksudkan untuk membantu individu atau kelompok individu muslim agar menyadari eksistensinya sebagai makhluk beragama yang harus senantiasa berpegangan pada nilai-nilai agama yang diyakini, serta menjadikan alQuran dan al-Sunnah Nabi sumber kekuatan moral bagi pelaksanaan aktifitas bimbingan atau konseling.

Namun, dari kedua istilah tersebut terdapat satu hal yang patut didiskusikan lebih lanjut, yaitu masalah penerapan istilah "Islam" pada istilah "Bimbingan" dan "Konseling” tersebut. Apakah yang dimaksudkan dengan kata "Islam" tersebut sebagai sebuah ajaran yang harus didekati secara teologis-keimanan, ataukah kata "Islam" tersebut mesti dipahami sebagai sebuah hasil ijtihad yang tentu saja bersifat historis. Pemakaian kata "Islam" yang dikaitkan dengan pembahasan sebuah disiplin ilmu (ilmu pengetahuan) yang menuntut adanya dimensi rasionalitas, pada dasarnya bukannya tanpa resiko. Bila kata "Islam" yang dimaksudkan sebagai sebuah agama atau ajaran, maka akan cenderung menyebabkan eksistensi suatu disiplin ilmu tersebut terjebak ke dalam tradisi tafsir atas text yang bersifat dogmatis-teologis. Eksistensi keilmuan seperti itu, 
pada akhirnya sulit sekali berkembang, karena orang-orang yang terlibat di dalamnya, secara psikologis, mengalami ketakutan "dicap sebagai kafir atau murtad" ketika dirinya memiliki konsep-konsep yang berbeda dari ketentuan doktrin yang dibakukan. Selain itu, pemakaian kata Islam itu sendiri ternyata banyak sekali "kepentingan" yang ikut campur, sehingga menyulitkan pemakaiannya ke dalam diskursus keilmuan. Sebaliknya, bila kata "Islam" tersebut dimaknai secara historis, yakni hasil pemikiran para pemikir Muslim era klasik, pertengahan dan kontemporer, maka hal ini terkadang sering "dicurigai" sebagai agen orientalis yang hendak melakukan proses "sekulerisasi agama" dalam tubuh Islam. Makna Islam sebagai agama ditakutkan akan tereduksi dan hilang kesakralannya (Amin Abdullah, 1995: 7-9).

Dari beberapa pengertian di atas pun, terlihat dengan jelas bahwa satu hal yang penulis nilai sebagai pembeda antara "Bimbingan Konseling Islam" dengan "Bimbingan Konseling” yang non-Islamis adalah terletak pada landasan spirit-moralitas pelaksanaannya yang disandarkan pada acuan petunjuk al-Quran dan al-Hadits. Penerapan landasan spirit-moralitas seperti itu, paling tidak dapat dilihat dari dua aspek yang masing-masing saling melengkapi, yaitu aspek konselornya dan aspek motif atau tujuan pelaksanaan bimbingan dan konseling. Seorang pembimbing/konselor yang melakukan aktifitas bimbingan atau konseling, dalam Bimbingan Islam atau konseling Islam, merupakan seorang yang memeluk agama Islam dan motif serta tujuan yang melatarbelakangi aktifitasnya tersebut berusaha didasarkan kepada nilai-nilai Islamis. Selain itu, dari beberapa pengertian di atas, bila dicermati melalui pandangan Pietrofesa tentang unsur-unsur dalam konseling, maka pengertian-pengertian di atas belum sepenuhnya memuat kreteria unsur konseling yang disampaikan Pietrofesa tersebut. Menurut Pietrofesa, proses bimbingan Konseling pada dasarnya memiliki 6 unsur, yang terdiri dari adanya proses pemberian bantuan, adanya seseorang yang dipersiapkan secara professional membantu orang lain, adanya tujuan untuk pemahaman diri klien sendiri, adanya pembuatan keputusan dan pemecahan masalah, adanya pertemuan dari hati ke hati, dan adanya hasil yang sangat tergantung pada kualitas hubungan (Andy Mappiere, 1992: 16-17). 
Oleh karena itu pengertian Bimbingan Konseling Islam, dengan berpijak pada kreteria Pietrofera tersebut, dapat dirumuskan sebagai berikut; bahwa Bimbingan Konseling Islam adalah suatu proses pemberian bantuan yang dilakukan oleh seorang konselor muslim terhadap klaien, agar mampu melakukan pemahaman terhadap dirinya sendiri dan mengambil keputusan untuk keluar dari permasalahan yang dihadapi, melalui suatu kwalitas hubungan yang hangat dan professional dengan didasarkan pada nilai-nilai Islami.

Untuk lebih jelasnya, gambaran tentang disiplin Bimbingan Konseling Islam tersebut terlihat pada bagan berikut:

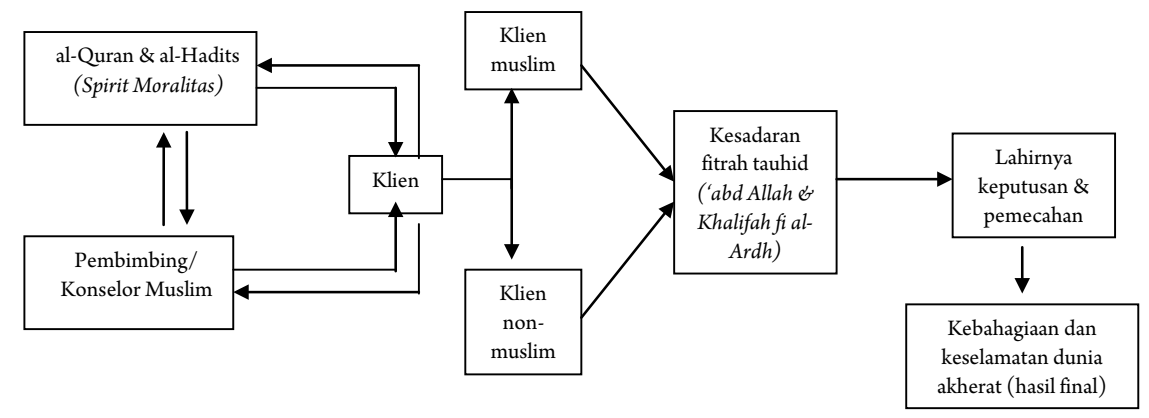

Setelah melihat berbagai definisi yang ada, muncul sebuah persoalan baru yang terkait dengan eksistensi aktifitas helping relationship dalam Bimbingan dan Konseling secara umum dan Bimbingan Konseling Islam secara khusus. Persoalan tersebut adalah apakah aktifitas pemberian bimbingan atau the helping relationship tersebut bisa dikatakan atau dikategorisasikan sebagai sebuah disiplin ilmu? Memang tidak mudah untuk memberikan jawaban yang memuaskan terhadap persoalan tersebut. Dalam tradisi filsafat pun, persoalan seperti itu juga terjadi dalam kasus metafisika, yaitu apakah metafisika bisa dikategorisasikan sebagai sebuah disiplin ilmu.

Terhadap persoalan seperti itu, Drs. Rizal Mustansyir, M.Hum dan Drs. Misnal Munir, M.Hum dalam bukunya yang berjudul Filsafat Ilmu menyebutkan bahwa metafisika tidak dapat dikatakan sebagai ilmu, bila yang dimaksud dengan ilmu itu sendiri adalah sesuatu yang persifat pasti (fixed) dan final. Tetapi, bila yang dimaksud dengan ilmu itu sendiri adalah sebuah penyelidikan yang dikaitkan dengan sikap (attitude) dan 
metode tertentu, maka metafisika pun juga dapat dikatakan sebagai ilmu (Mustansyir, 2001: 13). Meskipun harus diakui pula bahwa pemberian batasan yang kaku atau ketat terhadap eksistensi ilmu, justeru akan menimbulkan berbagai kontradiksi internal, apalagi bila pembatasanpembatasan terhadap konsep ilmu tersebut mengarah kepada bentuk ideologisasi ilmu(Chalmers, 1983: 187). Namun, sebaliknya, keabsurdan juga akan terjadi bila batasan-batasan tentang ilmu tersebut tidak diberikan. Karena hal itu juga akan menimbulkan ketidakjelasan kreteria yang bisa digunakan untuk membedakan jenis pengetahuan yang sering dinamakan ilmu dengan jenis-jenis pengetahuan lainnya. Oleh karena itu, menurut Jujun S. Sumantri, ada tiga aspek landasan filosofis yang bisa digunakan untuk menentukan perbedaan status ilmu tersebut dengan jenis-jenis pengetahuan lainnya. Ketiga aspek landasan filosofis tersebut adalah landasan ontologis, landasan epistemologis, dan landasan aksiologis (Suriasumantri, 1999: 35). Landasan ontologis bisa digunakan untuk merunut spesifikasi obyek atau hakekat apa yang dikaji, landasan epistemology digunakan untuk merunut prosedur, cara, dan sarana yang mesti dipakai untuk mendapatkan pengetahuan yang benar, dan landasan aksiologis bisa digunakan untuk merunut keterkaitan nilai kegunaan suatu ilmu dan juga relasinya dengan masalah tanggung jawab moral.

Ketiga landasan filosofis itulah menurut hemat penulis yang semestinya dirunut untuk menentukan status keilmuan Bimbingan Konseling Islam, di samping status legal-formalnya yang mesti dilihat dalam SK yang telah diterbitkan oleh fihak berwenang tentunya. Selain itu, untuk menentukan apakah aktifitas Bimbingan Konseling Islam bisa dikategorikan sebagai ilmu atau bukan, menurut hemat penulis, hal itu juga bisa dijelaskan berdasarkan aspek-aspek epistemologis yang mendasari. Menurut penjelasan Bahm disebutkan bahwa suatu kegiatan baru dapat dikatakan sebagai sebuah ilmu bila mencakup enam karakteristik, yaitu adanya problem (problems), sikap (attitude), metode (method), aktifitas (activity), pemecahan (solutions), dan pengaruh (effect) (Mustansyir: 13).

Jujun S. Suriasumantri menyebutkan bahwa pada hakekatnya suatu ilmu itu tidak dapat dilepaskan dari metafisika (Ibid: 69). Pandanganpandangan mendasar tentang alam dan segala realitas yang ada, pada akhirnya memiliki pengaruh terhadap perbedaan paradigma yang 
dikembangkan oleh berbagai disiplin keilmuan yang ada. Secara umum, pandangan-pandangan metafisis (ontologis) tentang alam atau segala relaitas yang ada tersebut dapat dipetakan ke dalam dua mainstream kecenderungan yang berbeda, yaitu pandangan-pandangan metafisis atau ontologis yang bercorak transcendental-supranaturalistik dan kedua bercorak humanismematerialistik. Pandangan metafisika transcendental-supranaturalistik lebih menekankan pada peran hal-hal yang bersifat transenden atau yang ghaib serta pengaruh yang ditimbulkannya terhadap setiap gejala yang terdapat dalam dunia empiric-sensual. Sementara, pandangan ontologis yang bercorak humanistic-materialis lebih menekankan pada peran manusia sebagai pusat penentu kebenaran dan setiap gejala/kejadian yang terdapat dalam alam diyakini tidak ada keterkaitan langsung dengan hal-hal yang bersifat roh atau ghaib. Atas dasar perbedaan pandangan fundamental seperti ini, misalnya, dalam tradisi keilmuan alam empiris yang cenderung kepada corak metafisika humanistic-materialis membangun tiga asumsi dasar yang dijadikan sebagai paradigma dalam memandang obyek-obyek empirisnya. Ketiga asumsi dasar tersebut, pertama adalah anggapan adanya keserupaan atau kesamaan satu sama lain dalam obyek-obyek tertentu, seperti kesamaan dalam hal bentuk, struktur, sifat, dan yang lainnya. Kedua adalah anggapan adanya keajekan atau kelestarian, yakni suatu benda tidak mengalami perubahan dalam jangka waktu tertentu, dan asumsi ketiga adalah anggapan adanya determinisme yang berpandangan bahwa setiap gejala yang terdapat dalam alam bukanlah merupakan suatu kejadian yang bersifat kebetulan, tetapi ia mempunyai pola-pola tertentu yang bersifat tetap dan dengan urut-urutan kejadian yang sama. Ketiga asumsi dasar seperti ini bila ditelusuri lebih lanjut akan bermuara pada gagasan ontologis yang bercorak humanistic-materialis, yaitu yang telah dibangun berdasar pandangan metafisis aliran materialisme-naturalistik. Aliran tersebut memiliki pandangan metafisika bahwa gejala-gejala alam tidak disebabkan oleh pengaruh kekuatan yang bersifat ghaib, melainkan oleh kekuatan yang terdapat di dalam alam itu sendiri dan yang dapat dipelajari.

Berdasarkan perbedaan corak ontologis-metafisis tersebut, sebenarnya tradisi-tradisi keilmuan yang ada dalam Islam bisa dirunut dan dibangun. Apakah aspek ontologis dari ilmu-ilmu keislaman hendak dikembangkan berdasarkan corak ontologis transcendental-supranaturalistik 
ataukah hendak dikembangkan berdasarkan paradigma ontologis humanisme-materialistik. Kedua pilihan tersebut bukannya tanpa resiko. Jika ilmu-ilmu keislaman hendak dikembangkan berdasarkan kerangka acuan ontologis yang bercorak transcendental-supranaturalistik, maka peran manusia sebagai penentu kebenaran mesti dibatasi, bahkan dinegasikan sama sekali. Tidak ada kuasa dalam diri manusia untuk menentukan kebenaran, karena semua bentuk penentuan kebenaran berada dalam wilayah dunia transenden, yakni Tuhan atau kekuatan supranatural. Semua kejadian yang terdapat dalam wilayah empiric-sensual hanya merupakan pengaruh yang ditimbulkan dari kekuatan di luar alam. Pola pemikiran seperti ini, bila dikembangkan dalam ilmu-ilmu keislaman akan melahirkan konstruksi ontologis ilmu-ilmu keislaman yang lebih diwarnai dan didominasi oleh paradigma-paradigma teologis-doktriner. Sehingga kecenderungan yang terjadi dalam setiap disiplin keilmuan dalam Islam lebih beraroma indoktrinasi, anti kritik, dan tidak menerima perubahan (ghairu qabil li al-niqas wa al-taghyir). Segala pemikiran yang berbeda dari ketentuan-ketentuan yang telah dibakukan dalam suatu disiplin keilmuan, cenderung dianggap sebagai bentuk penyimpangan dan seringkali dilabeli "kafir" atau "non-Islamis". Inilah yang penulis maksud dengan bukan tanpa resiko, jika corak ontologis yang dijadikan dasar pengembangan dalam ilmuilmu keislaman tersebut lebih bercorak transcendental-supranaturalistik. Resiko yang lain dari model ini adalah semakin menajamnya serta absurdnya perbedaan antara wilayah normative dan wilayah histories, dan ilmu-ilmu keislaman yang ada akan lebih berkutat pada wilayah normative saja, sehingga sedikit kemungkinan merambah ke dalam wilayah histories. Sebaliknya, bila ilmu-ilmu keislaman yang ada tersebut dikembangkan berdasarkan kerangka acuan corak ontologis yang bersifat humanismematerialistik maka pengembangan inovatif terhadap ilmu-ilmu keislaman tersebut akan mudah diusahakan. Karena pengembangan keilmuan dengan mendasarkan corak ontologis seperti ini cenderung memiliki keleluasaan yang lebih, lepas dari bayang-bayang ketakutan "dosa”, "murtad” atau kafir. Tidak ada lagi ketakutan untuk melakukan kritik atau perubahan setiap teori, ide, atau konsep-konsep keilmuan yang ada, karena penentu kebenaran yang sepenuhnya ada pada wilayah manusia (tidak teosentris lagi). Namun, usaha menempatkan corak ontologis yang bersifat humanisme-materialistik 
seperti ini, dengan tanpa disertai kritik, juga mengandung konsekuensi yang tidak kalah menakutkannya dari penerapan corak ontologis yang pertama. Karena, dengan meletakkan kerangka dasar ontologis humanismematerialistik seperti ini juga berpotensi menjauhkan eksistensi keilmuan dari "ruh kesucian" atau nuansa spiritual yang secara inhern melekat dalam diri ilmu atau pengetahuan itu sendiri (Nasr, 1997:156-159). Sebenarnya untuk menghindarkan resiko, atau paling tidak meminimalisir resiko yang harus ditanggung tersebut, masih ada satu kemungkinan penerapan corak ontologis lain dalam usaha mengembangkan sebuah eksistensi keilmuan, yaitu dengan menggunakan ontology yang bercorak Transendentalisme-Humanistik. Dalam corak ontology ini, peran manusia dalam memformulasikan konsep-konsep pengetahuan atau ilmu tetap dijadikan sebagai titik tolaknya, namun demikian formulasi keilmuan yang dibangun tersebut tetap berada di bawah naungan petunjuk Tuhan. Dengan demikian, dalam pengembangan disiplin-disiplin keilmuan keislaman yang ada akan selalu didasarkan pada hubungan dialogis antara wahyu atau normative yang merupakan wilayah transcendental, dan dengan kenyataan empiric atau wilayah histories. Upaya mendialogkan antara aspek humanis dan transenden seperti ini akan kembali meneguhkan pentingnya nuansa spiritual atau moralitas dalam pengembangan keilmuan yang ada (Supena, 2004: 267). Demikian halnya dengan pengembangan Bimbingan dan Konseling Islam, menurut hemat penulis hal itu juga perlu memperhatikan corak ontologis yang dijadikan sebagai dasar.

Dilihat dari landasan ontologis, aktifitas keilmuan Bimbingan Konseling Islam memiliki obyek kajian, baik obyek kajian materialnya ataupun obyek formalnya. Obyek material Bimbingan Konseling Islam berkaitan dengan apa yang menjadi sasaran atau bidang kajian, sedangkan obyek formalnya berkaitan dengan sudut pandang yang digunakan dalam melihat bidang kajiannya tersebut. Berdasarkan landasan ontologis tersebut dapat dikatakan bahwa bidang kajian atau obyek material Bimbingan Konseling Islam memiliki kesamaan dengan obyek material ilmu-ilmu sosial yang ada, yaitu manusia. Sedangkan obyek formalnya terletak pada hubungan saling membantu atau menolong yang terjadi di antara manusia (the helping relationship). Namun hubungan saling menolong tersebut dalam kenyataannya memiliki ragam bentuk yang berbeda-beda, 
menurut perbedaan aspek kedirian manusia. Jika bentuk aktifitas saling menolong tersebut terkait dengan aspek penyakit jasmani manusia, maka bentuk aktifitas keilmuan yang dikembangkan tersebut mengarah pada bentuk layanan bimbingan medis, yang secara factual telah dikembangkan dalam ilmu kedokteran. Jika aktifitas tersebut terkait dengan persoalan aspek penyakit jiwa (psikologis) manusia, maka aktifitas keilmuan yang dikembangkan tersebut lebih mengarah kepada bentuk layanan psikoterapis. Ahli yang melaksanakan praktek layanan psikoterapi sering disebut dengan "terapis". Sedangkan aktifitas layanan yang terkait dengan bantuan penyelesaian problem psikologis yang berupa ketidakberdayaan atau kebelumsadaran seseorang terhadap potensi dan kualitas dirinya, di mana hal tersebut seringkali menjadi pemicu berbagai persoalan psikologis, maka bentuk layanan seperti itu sering dikategorikan sebagai layanan bimbingan konseling. Ahli yang melaksanakan praktek layanan konseling seperti ini sering disebut "konselor". Perbedaan layanan psikoterapis dan bimbingan konseling lebih ditentukan oleh perbedaan setting tempat yang digunakan untuk menjalankan praktek layanan, tipe pelayanan yang diberikan, dan taraflatihan yang diterimanya (Corey: 12). Berdasarkan pemetaan karakter dan model kegiatan yang terdapat dalam proses the helping relationship tersebut, maka dapat diformulasikan obyek forma Bimbingan konseling secara umum berupa kegiatan pemberian bantuan yang dilakukan seorang konselor kepada orang lain yang tengah mengalami problem psikologis agar dirinya memiliki kemampuan untuk menyelesaikan permasalahannya secara mandiri, melalui suatu kwalitas hubungan yang hangat dan professional. Sedangkan obyek forma dalam Bimbingan Konseling Islam berupa kegiatan pemberian bantuan yang dilakukan oleh seorang konselor muslim terhadap klaien, agar ia mampu melakukan pemahaman terhadap dirinya sendiri dan mengambil keputusan untuk keluar dari permasalahan yang dihadapi, melalui suatu kwalitas hubungan yang hangat dan professional dengan didasarkan pada nilai-nilai Islami. Dilihat dari obyek formanya, aspek yang membedakan antara Bimbingan Konseling secara umum dengan Bimbingan Konseling Islam, hanya terletak pada status konselornya dan nilai-nilai normatif yang dijadikan landasan bagi kegiatan layanan bimbingan konseling. Namun perbedaan nilai-nilai normatif yang dijadikan sebagai spirit moralitas kegiatan layanan bimbingan konseling Islam tersebut, tidak harus memiliki 
konsekuensi logis bahwa secara ontologis konseling Islam berbeda secara mutlak dengan konseling-konseling pada umumnya. Kehadiran konseling Islam, dan keberadaannya, dapat disejajarkan secara horizontal, dan juga diperbandingkan, dengan keberadaan berbagai disiplin konseling yang dikembangkan oleh para ilmuwan lain. Dengan demikian adalah sah bila disiplin konseling Islam terkadang masih mengadopsi berbagai teori psikologi yang ada, untuk digunakan dalam memahami sisi-sisi psikologis seorang klien. Begitu pula juga seorang praktisi konseling Islam tidak bisa dipersalahkan bila dalam melakukan pemeriksaan terhadap kondisi psikologis klein menghasilkan hasil analisis yang berbeda dari teori-teori psikologi yang ada, selama hal itu bisa dipertanggungjawabkan secara ilmiah atau rasional.

Corak status ontologis dari konseling Islam yang bersifat transcendental-humanistik di atas, tidak harus menyebabkan keberadaan konseling Islam kembali terperangkap dalam wilayah keilmuan yang bersifat ghair qabil al-niqas wa al-taghyir atau taken for granted. Proses dan aktifitas helping relationship yang terdapat dalam konseling Islam samasama merupakan aktifitas kemanusiaan, seperti halnya proses-proses yang terjadi dalam praktik-praktik layanan konseling pada umumnya. Niat dan spirit moralitas Islam yang dijadikan motif oleh sang konselorlah, yang bisa membedakan status aktifitas konseling tersebut bernilai ibadah atau tidak. Hal seperti ini sejalan dengan sebuah riwayat yang mengatakan bahwa, "Banyak sekali amal perbuatan yang secara lahir bersiafat duniawi, namun karena ia dijalankan dengan niat yang benar, akhirnya menjadi amal akherat (bernilai ibadah). Sebaliknya, tidak sedikit seseorang menjalankan amal perbuatan yang bersifat ukhrawi, tetapi karena niat yang dimilikinya tidak benar, maka ia berupah menjadi amalan duniawi (tidak bernilai ibadah)."

\section{Konstruk Epistemologis dan Aksiologis Konseling Islam}

Bagaimana konstruk konseling Islam harus dibangun? Sumber dan metodologi seperti apa yang harus dimiliki. Berdasarkan kajian aspek ontologis di atas disebutkan bahwa bimbingan dan konseling Islam merupakan kegiatan pemberian bantuan yang dilakukan oleh seorang konselor muslim terhadap klien, agar ia mampu melakukan pemahaman terhadap dirinya sendiri dan mengambil keputusan untuk keluar dari 
permasalahan yang dihadapi, melalui suatu kwalitas hubungan yang hangat dan professional dengan didasarkan pada nilai-nilai Islami. Ada dua aspek yang perlu diperjelas terkait dengan kegiatan bimbingan dan konseling di atas. Pertama adalah status konselor-nya dan kedua landasan normatif yang dijadikan dasar bagi kegiatan bimbingan dan konseling di atas. Ada enam kemungkinan kegiatan bimbingan dan konseling berlangsung: pertama, proses bimbingan dan konseling yang dilakukan oleh seorang konselor muslim dan menggunakan nilai-nilai Islam sebagai landasan normatif kegiatannya. Kedua, proses bimbingan dan konseling yang dilakukan oleh seorang konselor muslim, tetapi tidak menggunakan nilai-nilai Islam sebagai landasan normatif kegiatannya. Ketiga, proses bimbingan dan konseling yang dilakukan oleh seorang konselor non-muslim, tetapi menggunakan nilai-nilai Islam sebagai landasan normatif kegiatannya. Keempat, proses bimbingan dan konseling yang dilakukan oleh seorang konselor non-muslim dan tidak menggunakan nilai-nilai Islam sebagai landasan normatif kegiatannya. Kelima, proses bimbingan dan konseling yang dilakukan oleh seorang konselor muslim dan menggunakan gabungan antara nilai-nilai Islam dan non-Islamis sebagai landasan normatif kegiatannya. Keenam, proses bimbingan dan konseling yang dilakukan oleh seorang konselor non-muslim dan menggunakan gabungan antara nilainilai Islam dan non-Islamis sebagai sebagai landasan normatif kegiatannya (Komarudin, 2007: 123).

Memang masih membutuhkan diskusi yang panjang untuk membedakan antara bimbingan dan konseling yang Islamis dan yang tidak Islamis. Bila kreteria yang digunakan untuk menentukan suatu kegiatan bimbingan dan konseling Islamis hanya didasarkan kepada aspek status konselor-nya yang harus merupakan seorang muslim, maka hal itu akan menimbulkan kontroversi dengan fakta kemungkinan kegiatan BK nomor (2) dan (5). Apakah kegiatan BKyang dilakukan seorang konselor muslim, tetapi tidak menggunakan nilai-nilai Islam atau dengan menggunakan gabungan antara nilai-nilai Islam dan non-Islamis sebagai landasan normatif kegiatannya, juga tetap bisa dikatakan sebagai model kegiatan bimbingan dan konseling Islam. Begitu pula, bagaimana status kegiatan BK yang dilakukan oleh seorang konselor non-muslim, tetapi menggunakan nilai-nilai Islam atau dengan menggunakan gabungan antara nilai-nilai 
Islam dan non-Islamis sebagai landasan normatif kegiatannya. Apakah hal ini juga tidak bisa dikatakan sebagai bentuk atau model kegiatan bimbingan dan konseling Islam.

Perdebatan itu semakin bertambah panjang ketika masalah yang didiskusikan tersebut menyangkut masalah nilai-nilai Islam. Semua umat Islam sepakat bahwa yang dimaksud dengan nilai-nilai Islam tersebut adalah seperangkat nilai yang terdapat dalam buku suci pedoman umat Islam, yaitu al-Quran dan al-Hadits. Tetapi, bagaimana memformulasikan ide-ide transendental dari Kitab Suci tersebut ke dalam konsep-konsep teoritis dan praktis sehingga bisa dijadikan sebagai landasan teoritis pengembangan suatu disiplin keilmuan yang Islamis, ternyata tidaklah mudah. Terdapat begitu banyak penafsiran dan pendapat dari para ulama dan cendekiawan muslim sendiri yang berbeda. Begitu pula, begitu banyak ideologi dan gerakan dalam tubuh umat Islam yang memiliki ragam metodologi dalam memahami ajaran Islam dalam kitab suci, al-Quran dan al-Hadits, serta berbagai kepentingan dan arah perjuangan yang berbeda-beda.

Untuk menghindari perdebatan yang panjang tersebut, maka model rumusan tentang bimbingan dan konseling Islam seperti di atas dipilih sebagai model pengertian BKI. Dengan demikian, ada dua hal yang perlu diperhatikan dalam konstruks keilmuan BKI, yaitu aspek konselor dan aspek nilai-nilai Islam yang dijadikan sebagai dasar dan landasan kegiatan profesi bimbingan konseling. Dilihat dari obyek formanya, aspek yang membedakan antara Bimbingan Konseling secara umum dengan Bimbingan Konseling Islam, hanya terletak pada status konselornya dan nilai-nilai normatif yang dijadikan landasan bagi kegiatan layanan bimbingan konseling. Namun perbedaan nilai-nilai normatif yang dijadikan sebagai spirit moralitas kegiatan layanan bimbingan konseling Islam tersebut, tidak harus memiliki konsekuensi logis bahwa secara ontologis konseling Islam berbeda secara mutlak dengan konseling-konseling pada umumnya. Kehadiran konseling Islam, dan keberadaannya, dapat disejajarkan secara horizontal, dan juga diperbandingkan, dengan keberadaan berbagai disiplin konseling yang dikembangkan oleh para ilmuwan lain.

Dengan demikian adalah sah bila disiplin konseling Islam terkadang masih mengadopsi berbagai teori psikologi yang ada, untuk digunakan dalam memahami sisi-sisi psikologis seorang klien. Begitu pula 
juga seorang praktisi konseling Islam tidak bisa dipersalahkan bila dalam melakukan pemeriksaan terhadap kondisi psikologis klien menghasilkan hasil analisis yang berbeda dari teori-teori psikologi yang ada, selama hal itu bisa dipertanggungjawabkan secara ilmiah atau rasional. Begitu pula, adalah sah-sah saja bila dalam praktiknya model-model diagnose permasalahan klien dan wawancara yang digunakan dalam proses bimbingan dan konseling Islam memiliki kesamaan dengan model-model diagnose dan wawancara dalam praktek-praktek bimbingan dan konseling yang ada pada umumnya. Dalam penggunaan berbagai metode konseling pun boleh jadi sama, tetapi juga tidak menutup kemungkinan diketemukannya sebuah metode yang lebih komprehensif dalam proses layanan bimbingan konseling. Misalnya, dalam suatu kasus seorang konselor dihadapkan pada kondisi klien yang bila diiagnose berdasarkan seperangkat teori dan metode yang ada, ternyata belum juga berhasil dideteksi. Tetapi, dengan menggunakan pendekatan agama atau konsep-konsep yang ada dalam agama, permasalahan yang "diderita" berhasil didianogsa dan klien pun bisa terbantu. Maka hal ini pun secara teori bimbingan dan konseling juga tak sepatutnya dipermasalahkan.

Begitu pula secara aksiologis, bimbingan dan konseling Islam tidak memiliki perbedaan yang signifikan. Secara umum, nilai kegunaan pelaksanaan bimbingan dan konseling Islam adalah memberikan bantuan kepada orang lain. Namun, dalam praktiknya secara khusus pelaksanaan bimbingan dan konseling Islam terkadang tidak bisa dipisahkan dari fungsi aksiologis dakwah Islam juga, yaitu membantu seorang klien agar kembali bisa hidup selaras dengan fitrah tauhidnya dan mendapatkan kebahagian serta kesejahteraan hidup di dunia dan akherat, serta selamat dari api neraka.

Berdasarkan uraian diatas, maka kembali dapat diringkaskan ideide pokok tulisan ini, sebagai berikut. Pertama, bahwa gagasan mengenai Islamisasi ilmu tidaklah harus berakibat pada lahirnya produk-produk keilmuan yang bersifat eksklusif dan "superioritas". Kedua, setiap disiplin keilmuan yang dihasilkan berdasarkan proses ijtihadi pasti bersifat histories. Oleh karena itu, status keberadaan keilmuannya tidak lagi harus ditempatkan sejajar dengan doktrin suci, sehingga bersifat ghair qabil li al-niqas wa al-taghyir atau bersifat taken for granted. Begitu pula 
keberadaan Konseling Islam, yang sudah sepantasnya tidak ditempatkan lebih tinggi di atas teori-teori konseling yang lain, atau disiplin-disiplin keilmuan konseling lainnya. Antara konseling Islam dan disiplin-disiplin konseling yang lain seharusnya ditempatkan sejajar, sehingga satu sama lain saling melengkapi dalam menyingkapkan "rahasia" yang terdapat pada proses atau aktifitas helping relationship, antara seorang konselor dan klien. Ketiga, proses konseling yang merupakan bagian dari aktifitas kemanusiaan, bila dijadikan sebagai salah satu obyek kajian keilmuan, seharusnya melahirkan suatu disiplin keilmuan yang bersifat histories. Oleh karena itu, pendekatan yang semestinya tepat untuk kajian mengenai hal itu lebih cocok bersifat humanistic-transendental, ketimbang teologistransendental. Keempat, berdasarkan kajian ontologisnya, antara konseling Islam dengan disiplin konseling lainnya, tidak memiliki perbedaan landasan ontologis yang signifikan. Di antara keduanya hanya dibedakan dari aspek status konselornya dan spirit moralitas yang dijadikan sebagai payung aktifitas konseling.

\section{Simpulan}

Setelah mencermati berbagai uraian diatas, maka kembali dapat penulis ringkaskan ide-ide pokok yang terdapat dalam uraian di atas, sebagai berikut. Pertama, bahwa gagasan mengenai islamisasi ilmu tidaklah harus berakibat pada lahirnya produk-produk keilmuan yang bersifat eksklusif dan "superioritas". Kedua, setiap disiplin keilmuan yang dihasilkan berdasarkan proses ijtihadi pasti bersifat histories. Oleh karena itu, status keberadaan keilmuannya tidak lagi harus ditempatkan sejajar dengan doktrin suci, sehingga bersifat ghair qabil li al-niqas wa al-taghyir atau bersifat taken for granted. Begitu pula keberadaan Konseling Islam, yang sudah sepantasnya tidak ditempatkan lebih tinggi di atas teori-teori konseling yang lain, atau disiplin-disiplin keilmuan konseling lainnya. Antara konseling Islam dan disiplin-disiplin konseling yang lain seharusnya ditempatkan sejajar, sehingga satu sama lain saling melengkapi dalam menyingkapkan "rahasia" yang terdapat pada proses atau aktifitas helping relationship, antara seorang konselor dan klien. Ketiga, proses konseling yang merupakan bagian dari aktifitas kemanusiaan, bila dijadikan sebagai salah satu obyek kajian keilmuan, seharusnya melahirkan suatu disiplin keilmuan yang bersifat 
histories. Oleh karena itu, pendekatan yang semestinya tepat untuk kajian mengenai hal itu lebih cocok bersifat humanistic-transendental, ketimbang teologis-transendental. Keempat, berdasarkan kajian ontologisnya, antara konseling Islam dengan disiplin konseling lainnya, tidak memiliki perbedaan landasan ontologis yang signifikan. Di antara keduanya hanya dibedakan dari aspek status konselornya dan spirit moralitas yang dijadikan sebagai paying aktifitas konseling. 


\section{BIBLIOGRAFI}

Abdullah, Amin, "Problematika Filsafat Modern: Pertautan antara Normativitas dan Historisitas", Makalah, disampaikan dalam Sarasehan dan Diskusi Jurusan Fakultas Ushuluddin Yogyakarta, tanggal 5 Januari 1995

Adz-Dzaky, Hamdan Bakran, Konseling dan Psikoterapi Islam, Yogyakarta: Fajar Pustaka Baru, 2001

Arifin, M, Bimbingan dan Konseling, Jakarta: Dirjen Bimbaga Islam dan Universitas Terbuka, 1994

Chalmers, A.F., Apa itu yang Dinamakan Ilmu?, terj. Redaksi Hasta Mitra, Jakarta: Hasta Mitra, 1983

Corey, Gerald, Teori dan Praktek Konseling dan Psikoterapi, terj.E.Koeswara, Bandung: PT Eresco, 1988

Efendi, Nur, (skripsi) Konsep Dzikir Muhammad Arifin Ilham sebagai Solusi Problematika Manusia Modern dan Implementasinya dalam Bimbingan Konseling Islam, Semarang: Fakultas Dakwah IAIN Walisongo, 2005

Fadholiyono, (skripsi) Dzikir dan Do'a sebagai Faktor Esensial Terapi MedikPsiiatrik: Studi Analisis Pengobatan Terpadu Prof.Dr.dr. Dadang Hawari dalam Perspektif Bimbingan KonselingIslami, Semarang: Fakultas Dakwah IAIN Walisongo, 2005

Faqih, Aunur Rohim, Bimbingan dan Konseling dalam Islam, Yogyakarta: UII Press, 2001

Mappiere AT, Andy, Pengantar Konseling dan Psikoterapi, Jakarta: Rajawali Press, 1992

Musnamar, Thohari, Dasar-Dasar Konseptual Bimbingan dan Konseling Islami, Yogyakarta: UII Press, 1992

Mustansyir, Rizal, dan Misnal Munir, Filsafat Ilmu, Yogyakarta: Pustaka Pelajar, 2001 
Nasr, Seyyed Hossein, Pengetahuan dan Kesucian, terj. Suharsono (et.all), Yogyakarta: Pustaka Pelajar, 1997

Prayitno dan Erman Amti, Dasar-Dasar Bimbingan dan Konseling, Jakarta: Rineka Cipta, 1999

Rosjidan, "Konseling bercorak Psikultural", Makalah, disampaikan pada pelatihan Tes bagi Konselor, 28 Juni - 13 Agustus 2004 di UNM.

Shertzer, Bruce and Shelly C. Stone, Fundamentals of Counseling, ed.3, Boston: Houghton Mifflin Company, 1980

Shertzer, Bruce and Shelly C. Stone, Fundamentals of Guidence, tk: Purdue University, 1966

Sukardi, Dewa Ketut, Pendekatan Konseling Karir di dalam Bimbingan Karir: Suatu Pendahuluan, Jakarta: Ghalia Indonesia, 1989

Supena, Ilyas, "Membangun Filsafat Ilmu Dakwah Dalam Perspektif Filsafat Ilmu-Ilmu Sosial”, Jurnal Ilmu Dakwah, Vol.24, No.2, Semarang: Fakultas Dakwah IAIN Walisongo, 2004

Suriasumantri, Jujun S., Filsafat Ilmu, cet.12, Jakarta: Pustaka Sinar Harapan, 1999

, Filsafat Ilmu Sebuah Pengantar Populer, Jakarta: Pustaka Sinar Harapan, 1999

Walgito, Bimo, Bimbingan dan Penyuluhan di Sekolah, Yogyakarta: Andi Offset, 1995 